\title{
"THAT NO MAN LIVES FOREVER": HORACE ON THE DEATH OF QUINTILIUS (1.24)
}

\section{Sjarlene Thom (University of Stellenbosch)}

On a first reading of Horace's Ode on the death of Quintilius (1.24) it seems that Horace has written a rather traditional poem of mourning: a poem which praises the dead man, which attempts to console mutual friends and which even seems to chide excessive mourning. ${ }^{1}$ This reading is perhaps to be expected since Horace's ode on the death of Quintilius has never been considered particularly obscure. The poet's primary aim in the composition of this ode seems to me, however, to express neither an appreciation of Quintilius (Nisbet \& Hubbard 1970), nor an admonition to Vergil for excessive mourning (Akbar Khan 1967). Furthermore, it does not even function as a consolation proper for all who mourned Quintilius' death (Esteve-Forriol 1962). ${ }^{2}$ If the poem is read as it stands, it conveys a different primary aim altogether even though appreciation for Quintilius is expressed, even though there are hints that Vergil could channel his mourning more constructively and finally that some consolation can be gleaned from creative activity.

\section{Horatius Carmina 1.24}

Quis desiderio sit pudor aut modus tam cari capitis? praecipe lugubris cantus, Melpomene, cui liquidam pater vocem cum cithara dedit.

5 ergo Quintilium perpetuus sopor urget; cui Pudor et Iustitiae soror incorrupta Fides nudaque Veritas quando ullum inveniet parem?

9 multis ille bonis flebilis occidit, nulli flebilior quam tibi, Vergili. tu frustra pius, heu, non ita creditum poscis Quintilium deos.

13 quid? si Threicio blandius Orpheo auditam moderere arboribus fidem, num vanae redeat sanguis imagini,

1 In this paper on Horace's ode on the death of Quintilius I shall not dwell on the imitative aspects of the poem which have been spelled out so clearly by various scholars (Nisbet \& Hubbard 1970; Esteve-Forriol 1962). Nor do I intend to discuss genre at any proper length, since calling this poem an epikedeion or elegy does not fundamentally aid our understanding of its meaning even though it is instructive to note how Horace used some aspects of the genre compared to, for instance, Archilochos or Catullus.

2 Nussbaum (1981:2101 n.25) maintains that "speculation about the circumstances of the poem should not obscure the meaning of the poem, however". 
quam virga semel horrida

17 non lenis precibus fata recludere

nigro conpulerit Mercurius gregi?

durum: sed levius fit patientia

quidquid corrigere est nefas.

What restraint or measure should there be to longing

for someone so dear? Teach songs of mourning,

o Melpomene, to whom the Father has given a melodious

voice as accompaniment to the lyre.

5 Everlasting sleep, then, confines Quintilius;

when will restraint and Justice's sister,

unalterable Loyalty, and uncompromising Truth

ever find an equal to him?

9 He died, his death brought tears to many good people,

none more tearful than you, Vergil.

You, in vain devoted, alas, in vain claim Quintilius,

not thus entrusted, from the gods.

13 What? Even if you were to sound the lyre, heard by the trees, more persuasively than Thracian Orpheus,

would blood then return to the empty form,

which, with repulsive wand

17 Mercury, not inclined to unlock the gates of death because of prayers, has joined to the dark flock?

It is hard, but that becomes easier with patience

which is wrong to change.

Most people exposed to the opening phrase of Horace's Ode 1.24 would take the introductory statement quis desiderio sit pudor aut modus tam cari capitis? (vv.12b) as a rhetorical question, since deeply felt emotion fundamentally disturbs or even challenges acquired characteristics such as pudor and modus. ${ }^{3}$ In Horace's opening statement the dilemma posed by an attempt at dealing with overwhelming feeling/longing (desiderio) is clearly indicated: no external action can adequately represent internal emotional experience. In short, the sphere of influence of concepts such as pudor or modus does not normally include that of profound personal feeling where desiderio and tam cari capitis operate. ${ }^{4}$ It is important to note, however, that at this stage in the poem Quintilius has not yet been identified, nor has the cause of desiderio nor the need for pudor or modus been made clear. In other words, the rhetorical question is completely open.

What to 'do' with profound feeling, is the problem. The phrase praecipe lugubris cantus (vv.2-3) which follows the rhetorical question seems to underline

3 Contra Akbar Khan (1967:109) who reads the lines as an indirect question. This would only be possible if Vergil and Quintilius had already been identified in the poem.

4 Kiessling \& Heinze (1930:106) consider pudor "mit modus fast synonym." 
the fact that there is no answer to the question just posed. At the same time, however, this phrase for the first time clearly identifies the overwhelming feeling concerned in the poem as grief. It focuses directly on the essence of the problem which the bereaved person faces: he does not know how to cope with his pain. If Melpomene teaches such a person how to respond to his situation, he may be able to come to terms with the situation itself.

It is striking that the response called for in this bridge passage (vv.2b-4) between the rhetorical question in vv.1-2 and the possible solution to the problem worked out in the rest of the poem, seems not to respond to the conflict between action and feeling identified in the rhetorical question at all. The bridge passage (vv.2b-4) side-steps the problem, as it were, by putting immediate reality aside for a while and moving into the world of gods and poetry instead: praecipe lugubris cantus, Melpomene, etc. (vv.2-4).5

The rest of the poem can be taken to represent the lugubris cantus taught by Melpomene (vv.2-3). The broad structure of the cantus is as follows: The dead person is identified for the first time in vv.5-6 and something of the essence of the man is indicated (vv.6-8). How this death affects others (vv.9-10) and continues to affect others (vv.11-12) is the central point of the cantus, reflecting the reason for its composition. In the next six lines (vv.13-18) the Orpheus example from mythology not only universalises the problem of bereavement, but also reminds present sufferers of the futility of not accepting the inevitable. The final two lines of the poem return to the reality reflected in the introductory rhetorical question. These verses also sum up the two separate sections of the cantus: v.19 refers to the death of Quintilius as described in vv.5-12 and v.20 comments on the essential problem in the Orpheus myth, namely that Orpheus' action was nefas, attempting as it did to transgress the laws of nature.

The structure of the poem can be represented schematically as follows:
A What to do with overwhelming grief?
vv.1-2a
Bridge passage: let an immortal teach the appropriate response $\quad v v .2 b-4$
B The cantus:
dead person identified
vv. 5-6
the essence of the man
vv.6-8
the effect of his death on others
vv.9-12
C Parallel situation in myth: Orpheus
vv.13-18
$B^{1}$ Response to description of Quintilius' death (vv.5-12)
v.19
$C^{1}$ Response to the Orpheus alternative (vv.13-18)
v. 20

On a first reading the cantus does not seem to succeed as a consolatio. The sections on Quintilius (vv.5-12) and Orpheus (vv.13-18) are nearly equal in length, a quarter

5 Melpomene only later becomes the Muse of Tragedy (Muthmann 1967:29). In this bridge passage her suitability as a teacher is made clear. She works through sound-the most pervasive sense to affect mood. 
of the lines focuses on Vergil in a seemingly haphazard and repetitive fashion and finally, the Orpheus myth appears to write off the dead as a flock of insubstantial shades, devoid of all individuality. If, however, one looks more closely at what Horace has written, one is forced to come to the conclusion that the cantus we have in front of us is inspired and indeed worthy of Melpomene herself. It is, however, very important to note that this poem is not necessarily intended as an elegiac consolatio but rather as a lyric cantus lugubris. It is in the first place an attempt to express the feelings evoked by the death of Quintilius. If some consolation springs from a dignified and formal expression of such feelings via a song of grief, that is only possible because the cantus has succeeded as a song (and incidentally has given overwhelming grief some shape).

The poem gives form to bereavement by focusing on individual steps in the process. ${ }^{6}$ One of the most difficult aspects to face when first confronted by the death of a beloved friend or family member, is the very fact of such a death. It is therefore of primary importance that the opening statement of the cantus affirms the fact that Quintilius is indeed dead, even though the words used are understated: ergo Quintilium perpetuus sopor / urget (vv.5-6); sleep, then, has Quintilius in thrall, everlasting sleep. One notes the importance of ergo especially, meaning that the audience is confronted directly by the fact of Quintilius' death. ${ }^{7}$

Once the fact of death has been confronted, the next aspect the bereaved has to face is an assessment of the loss suffered-even if only in the most general terms. In this case, some of Quintilius' special qualities are mentioned: Pudor, Fides (as soror lustitiae) and Veritas. At the same time these qualities in Quintilius are personified. They are viewed as goddesses who will never find a supporter equal to Quintilius to embody their characteristics. This personification implies that the qualities embodied by Quintilius are also timeless, that a timeless norm exists for these qualities. Such an abstract, timeless norm can never be subjected to change or death. By personifying personal qualities of Quintilius, these personal characteristics of the man are linked to the timeless norm. Quintilius as a man was honourable, loyal, truthful and since these qualities are timeless they will keep reminding others of him. ${ }^{8}$ In this way, what Quintilius was, will never change, even though he has ceased to exist. Horace compensates for the loss of Quintilius by reminding his audience of the continued existence of some of the qualities he embodied. In this way the cantus does not operate as a threnody for Quintilius in the first place, but as an expression of grief and desire for consolation, felt by those who remained behind to mourn the man who embodied such qualities.

$6 \quad$ Nussbaum (1981) refers to a sequence of key moments concerning Quintilius' death. I agree that the poem reflects a sequence of key moments but not concerning Quintilius' death (the literal news of his death, the view of his body and the funeral) as Nussbaum sees it. To my mind these key moments rather reflect the subsequent steps in the process demanded by bereavement when coping with Quintilius' death.

7 Syndikus (1972:239) also stresses the importance of ergo.

8 Contra Nisbet 1970:195: “These abstractions tell us nothing about Quintilius.” 
In the next stanzas (vv.9-12) the effect of Quintilius' death on other people is depicted. Since the fact of death is no longer an aspect which needs to be faced, no understatement is used for the verb occidit, to die. In this stanza the emphasis is on the effect Quintilius' death has had on many others (v.9) but especially on Vergil (v.10). In the last two lines of this stanza the cantus reflects great empathy for the normal reaction of any bereaved: it would be easier to change the laws of nature than to cope with all this pain. The basic tension between the normal acceptance of these laws of nature and the desire for an exception 'just in this case' is reflected very clearly in the contrast between frustra and pius at the beginning of v.11 as well as by the position of frustra precisely between tu and pius. ${ }^{9}$ Trying to eliminate the physical fact of death is not to understand the essence of life: non ita creditum Quintilium (v.11). Creditum is used as a simple economic metaphor to underline the fact that Quintilius was never an object owned by his friends, which could be demanded back like a loan can be reclaimed. Someone described as pius (as Vergil is described here) is therefore acting against his own nature if he refuses to accept death as a part of life.

The last section of the poem (vv.13-18) drives some of the points mentioned earlier in the cantus to their logical conclusion. The entire preceding section (vv.912) dwelt on the desire to counteract the laws of nature by reversing the physical fact of death. Orpheus exemplifies this natural desire. It is important to note, however, exactly which aspects of the myth are incorporated into Horace's six-line summary. Orpheus and his talent are mentioned only in passing, since the world of myth does not operate under the same laws as those of the physical world. Vergil has to cope with the real world, not a world where his talent is able to suspend reality or the laws of nature. 10 Jupiter may have given Melpomene her talent (and she in turn may inspire Virgil as well as Horace to create their poetic worlds) but nothing can change the order of nature and its physical reality.

The introductory quid (v.13) of the exemplum refers back to the initial rhetorical question posed by quis (v.1). There is no physical possibility of reconciling the world of the dead with the world of the living. There remains only an emotional acceptance of the fact of death. Some pointers have been given at the beginning of the cantus. Since pius is the important word, central to the preceding section in vv.5-12 as well as in the following section in vv.13-18, it is quite clear in which way quis desiderio sit pudor aut modus tam cari capitis (vv.1-2b) must be answered: one copes with death either as a pius human being accepting the laws of nature and the normal limits of life (which is in fact that death is part of life) or as an Orpheus who insists on the 'exceptional' only to be confronted by the real horror of death completely separated from life.

9 Kiessling \& Heinze (1930) take frustra as adverb with poscis, not with pius as does Wagenvoort. Cf. p.107: "ob man versteht 'fromm forderst du vergebens' oder (wohl besser) 'vergebens fromm forderst du' macht nicht viel aus."

10 Akbar Khan (1967:113) argues that Vergil is usurping the role of the gods where is poscit qui credidit. Nussbaum (1981:2107 n.45) adds divis a te to creditum. 
To take the Orpheus exemplum literally, namely that Vergil is acting against the laws of nature as Orpheus did, is to deny the universal impact of the myth. Of course Vergil cannot bring Quintilius back to life, even if he wants to. The whole point of the exemplum is not to function as an encomium of Orpheus' talent (or of Vergil's for that matter), which enabled a human being to penetrate the underworld. The details selected by Horace in the exemplum rather emphasise the horror and the futility of the whole experience when the consequences of not accepting death are pushed to their logical conclusion. The myth exemplifies what happens when a human being demands someone back from the gods against the laws of nature. The myth in fact, embodies both tu frustra pius as well as tu frustra ... poscis (vv.1112).

The Orpheus exemplum (vv.13-18) underlines the immediate emotional crisis which confronts the bereaved. Not only does the bereaved have to cope with the permanent physical absence of the dead, but he also has to face the fact that the dead now forms part of a world which is completely alien and therefore even frightening or repulsive to the living as reflected in phrases such as virga horrida (v.16) and nigro ... gregi (v.18). In other words, not only does the bereaved have to accept the fact of Quintilius' death, but he also has to face the physical implications of this death. It is with a measure of relief that the poem's focus shifts away from Quintilius dead to concentrate on who and what Quintilius was when still alive. The point is further that when the implications of Quintilius' death are not fully realised, the meaning of his life cannot be fully appreciated either.

The last two lines of the ode refer back to the two main sections of the poem. Verse 19 ("it is hard but it becomes easier with patience") refers to the section in the poem where it was clear that emphasis on Quintilius' qualities (vv.6b-8) formed a buffer between the fact of his death (vv.5-6a) and the pain which that fact caused his friends in general and Vergil in particular (vv.9-10). What Quintilius was (vv.6b-8) should somehow have an effect on how his friends experience the pain of his death (vv.5-6a). Verse 19 reflects how a pius person manages to cope with death.

The final verse, "that which is wrong to change" (v.20), refers to the Orpheus exemplum (vv.13-18). In Horace's selection of details the myth underlines the horror of an unnatural and pathetic attempt to side-step the god-given laws of nature. Even poetry is not capable of bringing the dead back to life. After all, in Vergil's own version of the myth, Orpheus' grief led to self-destruction. ${ }^{11}$

In the final analysis the last two verses of the ode respond directly to the opening question of the poem: quis desiderio sit pudor aut modus tam cari capitis? The choice is clear: either one comes to grips with suffering even though this learning process takes time (patientia), or the rhetorical question at the beginning of the poem is answered as it was never intended to be answered: by a choice for what is nefas.

11 Vergil's description of Orpheus' descent into the underworld was published in Georgicae 4 in 29 B.C. and Ode 1.24 in $24 / 23$ B.C. It is striking to note how closely the tone as well as the details of Horace's description of the underworld mirrors that of Vergil. 
Horace's poem on the death of Quintilius reflects Melpomene's inspiration indeed, in meaning as well as in form. Horace himself refers to his poem as cantus lugubris. The cantus works in two closely related ways. On the one hand it is an analysis of grief. On the other hand it identifies and deals with each consecutive step of the process which must be worked through when coming to terms with bereavement. Without the analysis the process does not get under way. At the same time, according to the poet, each step in the analysis depends on a firm understanding of where the process is at the moment and where it is leading.

Horace includes this ode in a book of lyric poetry. It is clear that the primary aim of the poem is an expression of the poet's personal response to the death of Quintilius. In short, the poem expresses a lyric response to bereavement. The poem might have elegiac or epikedeic overtones, but it remains lyric in conception and execution. The poem is concerned with giving form to the process required to cope with bereavement and the personal choices involved. If, in the process of this personal expression of one individual's experience, Quintilius is praised and some others are reprimanded or consoled, these are secondary benefits completely dependent on the success of the lyric poem. Longing for Quintilius has been expressed with restraint and the road not (to be) taken clearly indicated. The poem itself has epitomised something of the quality of the man Quintilius. At the same time it also expresses an everlasting and real remembrance of Quintilius in a form (the poem) which alone can and will transcend death. Poetry (even that of an Orpheus or Vergil) cannot restore life. Poetry, however, can, as it does here, commemorate life (Lowry 1994:379).

There is no direct evidence in the poem that Horace meant to chide Vergil into commemorating Quintilius restrainedly in writing, as he himself has just done. 12 Horace's grasp of loss and bereavement is profound. Such a loss cannot respond to mere admonition. It seems somehow more acceptable to see Horace's poem as a poem which expresses his own grief and which also reflects where he is in this process of confronting bereavement. In other words, his poem is an example of a possible reaction to the death of Quintilius, not a lesson of how to react to such a death.

The poem clearly has three equally important components: Horace, the death of Quintilius, and Vergil, or more generally the poet, his subject and audience. To focus on praise for Quintilius, or admonition and/or consolation for Vergil exclusively, is to deny the lyric poet his raison d'être: the personal voice, the expression of a personal point of view.

There are however, Vergilian echoes throughout the poem as well as the very significant reference to blandius ... Orpheo fidem moderere (v.13-14). Earlier in the poem the abstract quality Fides is called incorrupta (v.7). One is tempted to wonder whether Horace could not have meant these echoes and direct references as an

12 Contra Akbar Kahn (1967) who suggests that advice to Vergil on his conduct is more important in this poem than commemorating Quintilius. 
indication that grief for their friend Quintilius could, but not necessarily should, become an expression of incorrupta Fides if Vergil's talent gave permanent expression to that grief. After all, Vergil's talent, like Horace's, is a gift from the gods, even though their friend Quintilius is no longer such a gift. Furthermore, whom Melpomene is to teach in vv.2-3 is not specified ${ }^{13}$ and cantus in v.3 is plural. 14

But we are not discussing the pastoral effectiveness or consolatio function of Horace's poem, even though this aspect seems to me to be embedded in the personal or lyric perspective reflected in the poem. Instead I would also like to take the placing of Ode 1.24 in this first volume of lyric poetry into consideration to obtain a broader perspective on the meaning (and the possible effectiveness) of this poem. 15

The Quintilius poem is immediately preceded as well as followed by two completely different poems. Ode 1.23 is directed to a young girl named Chloë-very appropriately, since her name in Greek means 'green shoot' or 'branch'. Horace compares her to a skittish fawn, absurdly afraid of everything, even the most innocent natural occurrence like breezes in the woods, the coming of spring, and small creatures like lizards responding to the warmth. The young fawn/girl obviously does not understand that or how it/she is linked (even by name) to the natural cycle just evoked by the poet. Just as it is not always easy to accept death as a natural part of life, as in the Quintilius poem, growth too is part of this natural cycle and can be overwhelming, depending on one's perspective. In the last stanza of Ode 1.23 Chloë has to accept the same inevitable truth as Quintilius' friends. She cannot postpone being caught up by life just as Quintilius' friends cannot postpone accepting his death. 16

The Chloë and Quintilius poems are also very closely linked metrically, since both use variations of the Asclepiad. Indeed only the third verse of each stanza differs between the two poems: the Chloe poem taking a Pherecratean instead of a first Asclepiad. All other verses correspond.

13 Contra Nussbaum (1981:2101 n.23) who wants praecipe (teach) to imply only mihi.

14 On another level this example of 'poetic work' could also be seen as a possible response to the initial rhetorical question of 'what to do' with profound and overwhelming feeling. See also Lowry 1994:380.

15 It has long been accepted that adjacent odes have some influence on one another. Collinge (1961:52) states: "No doubt such is the motivation for following the moving reflections on Quintilius' death (1.24) with the shock of Parcius iunctas fenestras ..., the crudest and nastiest poem in Horace's lyrics." Pascal (1969:622) maintains that "good reasons can be found for having placed it [Ode 1.24] in a spot which is at first sight so disadvantageous" [i.e. between Odes 1.23 and 1.25 ], but does not come up with any truly convincing reason for placing the Quintilius Ode where it is. Fuqua (1968:45) also suggests that "nature as a standard for human conduct" is used as an organising principle to link odes 1.23, 24 and 25. Nature repeats her cycle but human beings have "but one cycle" to complete.

16 Cf. Nielsen 1970 for an analysis of the development of the animal metaphor in the Chloe poem; Ancona (1989) discusses the Chloë poem in terms of an expression of male desire portrayed directly (in rational discourse) as well as indirectly (through figurative language). 
Another more philosophical aspect hinted at by the Chloë poem also prepares the way for the Quintilius poem. Chloë is at the beginning of her life. What will become of that life is open. At Quintilius' death his friends can look back in gratitude for an exceptional life. Chloë's open-ended life filled with 'possibilities' is a foil for Quintilius' achievements. Her life might turn out any way. His life turned out so well that his death is a great loss to all who knew him. In short, the Chloë poem subtly reminds the audience of the Quintilius poem that no human being can be called truly happy until the end of his/her life.

The Lydia poem, Ode 1.25, is the Chloe poem in reverse. The dry leaves (aridas frondes) at the end of 1.25, for instance, link this poem to the 'young shoot', Chloë, in Ode 1.23. Admittedly, it is a completely independent poem, quite different in tone and metre from the two preceding poems. Even so, it does add a postscript to Ode 1.24 which should not be overlooked. Horace's Ode 1.25 reflects the regret it is possible to feel at the end of an unfulfilled life. It matters little that this regret is offered to someone not yet at the end of her life. Nor does it matter that Horace is here driving the exclusus amator convention to its logical conclusion or beyond (Catlow 1976). The last three stanzas of Ode 1.25 portray very graphically the circumstances and feelings of a human being who has misspent her life. In this way this life too becomes a foil for the life of Quintilius, since it reminds the audience that only the dead can be said to have had a happy life.

In my analysis of Ode $1.24 \mathrm{I}$ have tried to emphasise that the poem is an attempt to face Quintilius' death in a way meaningful to the lyric poet. In the first place it is an expression of grief at the loss of Quintilius and not an attempt to praise him or to comfort others because of this loss. 17 It is a dirge rather than a consolatio, a 'Trauergedicht', rather than a 'Trostgedicht'.

The consolatio aspect is not ignored, however, even apart from the fact that the poem can be taken as proof that Melpomene did teach Horace a cantus lugubris and did indeed show Horace a way to temper his own grief, as a result of which some personal consolation is brought to the poet. In my opinion the less personal, more general consolatio is dealt with outside Ode 1.24 , in Odes 1.23 and 1.25 where someone waits either on the brink of life not knowing what the future may have in store for her, or looks back on life with a terrible sense of regret. Quintilius on the other hand can now be called happy. Because of the impersonal assessment, as it were, by the two adjacent poems of other types of lives, Quintilius' friends can take comfort and find ongoing consolation in the realisation that their mourning cannot in truth be for someone they can describe as happy, but only for their own profound sense of personal loss.

17 Contra Nussbaum (1981:2113) who insists that the poem's purpose is "to help the other [Vergil] deal with his pain." This position undermines Nussbaum's own statement that Horace "has made an authentic journey through one specific experience of bereavement and, in terms of that experience, into something universal in the human condition". 


\section{BIBLIOGRAPHY}

Akbar Khan, H 1967. Horace's Ode to Virgil on the Death of Quintilius: 1.24. Latomus 26, 107-117.

Ancona, R 1989. Horace Odes 1.23 and the Construction of Male Desire. Helios $16 / 1,49-56$.

Catlow, L W 1976. Horace Odes 1,25 and IV,13: A Reinterpretation. Latomus 35, 813-821.

Collinge, N E 1961. The Structure of Horace's Odes. London: Oxford University Press.

Esteve-Forriol, J 1962. Die Trauer- und Trostgedichte in der römischen Literatur: Untersucht nach ihrer Topik und ihrem Motivschatz. Diss. München.

Fuqua, C 1968. Horace Carm. 1.23-25. Classical Philology 63, 44-46.

Kiessling, A \& Heinze, R 1930. Quintus Horatius Flaccus: Oden und Epoden. Berlin: Weidmannsche Buchhandlung.

Lowry, M 1994. Lyric's Elegos and the Aristotelian Mean. Classical World 87(5), 377-394.

Muthmann, F 1967. Trost und Mass: Gedanken zur Ode I.24 des Horaz. Altsprachliche Unterricht 10, 29-33.

Nielsen, R M 1979. Horace Odes 1.23: Innocence. Arion 9, 373-378.

Nisbet, R G M \& Hubbard, M 1970. A Commentary on Horace: Odes, Book I Oxford: Clarendon.

Nussbaum, G 1981. Sympathy and Empathy in Horace. Aufstieg und Niedergang der römischen Welt II.31.3, 2093-2159.

Pascal, C B 1969. Horatian chiaroscuro: Carm. I,24. In Bibauw, J (ed.), Hommages a Marcel Renard, vol. 1, 622-633. Bruxelles: Latomus. (Collection Latomus 101.)

Quinn, K 1980. Horace: The Odes. London: Macmillan.

Syndikus, H P 1972. Die Lyrik des Horaz. 1. Bd Darmstadt: Wissenschaftliche Buchgesellschaft. 